\title{
Penggunaan Model Prediksi Kawan Pada Mata Pelajaran Matematika Peserta Didik Kelas III Semester Dua Tahun Pelajaran 2018/2019 di SD Negeri 38 Ampenan Upaya Meningkatkan Motivasi Dan Hasil Belajarnya
}

\author{
Mardiana \\ Guru Matematika SD Negeri 38 Ampenan
}

\begin{abstract}
Abstrak. Penelitian ini bertujuan untuk mengetahui efektifitas penerapan model Prediksi Kawan dalam upaya meningkatkan motivasi dan hasil belajar matematika peserta didik Kelas III SD Negeri 38 Ampenan. Manfaat penelitian ini adalah sebagai bahan kajian dan bahan temuan dalam pelaksanaan proses pembelajaran di kelas senyatanya. Bagi guru untuk meningkatkan kompetensi dalam proses pembelajaran dan bagi siswa untuk meningktakan motivasi belajar yang berdampak meningkatnya hasil belajar siswa.Penelitian ini dilaksanakan dua siklus, masing-masing siklus kegiatannya adalah; perencanaan, pelaksanaan, observasi dan refleksi. Hasil akhir tindakan pada siklus II pertemuan II menunjukkan bahwa hasil observasi guru memperoleh skor rata-rata $(4,71)$ dan hasil observasi siswa mencapai skor rata-rata (4,51). Sedangkan dampak dari peningkatan motivasi belajar adalah meningkatnya perolehan hasil belajar siswa mencapai nilai rata-rata $(79,55)$, artinya indikator keberhasilan $(\geq 4,0)$ telah terlampaui. Karena indicator keberhasilan telah terbukti penelitian dinyatakan berhasil dan dihentikan pada siklus II.
\end{abstract}

Kata Kunci : Motivasi dan Hasil Belajar - Model Prediksi Kawan.

\section{PENDAHULUAN}

\section{Latar Belakang}

Model pembelajaran yang menuntut kerjasama dalam kelompok, team building perlu dibangun semenjak awal. Hal ini dimaksudkan agar peserta didik dapat secepatnya teman-temannya sehingga pada akhirnya mereka dapat bekerjasama dalam kelompok. Model pembelajaran ini merupakan salah satu cara yang cukup baik untuk membantu peserta didik mengenal satu sama lain. Model pembelajaran ini juga dapat menjadi salah satu eksperimen menarik pada pertemuan pertama dari suatu pembelajaran, yang bias dilanjutkan pada pertemuanpertemuan berikutnya. Pembelantukan kelompok sesuai dengan model pembelajaran ini diupayakan berbeda teman, berbeda karakter dan berbeda tingkat intelektualnya. Sehingga dalam pembentukan kelompok diupayakan tiap-tiap kelompok mempunyai anggota yang sepadan dan diupayakan tidak ada kelompok yang menonjol dan anggotanya khusus yang pintar-pintar saja (dihindari).

Kegiatan pembelajaran di SD Negeri 38 Ampenan khususnya di kelas III pada mata pelajaran matematika selama ini sudah mengacu pada pembelajaran peserta didik aktif dengan mengedepankan diskusi kelompok/kerja kelompok. Dalam kenyataannya masih belum berjalan sebagaimana perencanaan/scenario pembelajaran yang telah disiapkan. Lebih rinci kondisi pembelajaran selama ini dapat dijelaskan sebagai berikut; 1) ketika guru menyampaikan materi pelajaran masih saja dijumpai peserta didik yang rebut sendiri, bermain-main, dan ada pula yang tertidur lelap diatas meja duduknya, 2) pada saat peserta didik melakukan diskusi kelompok/kerja kelompok, terkesan hanya itu itu saja yang bekerja, selebihnya mencari kesibukan sendiri, 3) pada saat masingmasing kelompok tampil didepan untuk mempertanggungjawabkan hasil kerja kelompok, saling tunjuk tidak ada yang berani tampil memaparkan di depan kelasnya.

Rendahnya motivasi dan hasil belajar mata pelajaran matematika peserta didik kelas III semester dua tahun pelajaran 2018/2019 di SD Negeri 38 Ampenan disebabkan; 1) kondisi peserta didik ketika menerima materi pelajaran dari guru masih belum menunjukkan sikap serius, masih kurang aktif dan cenderung mencari kesibukan sendiri, 2) karakter peserta didik dalam hal keberanian 
tampil didepan kelas masih sangat rendah, kecendrungan hanya ketua dan sekretaris kelompok saja yang berani bersuara, sedangkan yang lain hanya diam dan pasif, 3) rendahnya mental peserta didik ketika sedang melaksanakan diskusi kelompok/kerja kelompok. Rata-rata hanya ketua dan sekretaris kelompok saja yang aktif memecahkan masalah yang diberikan oleh guru kepada kelompoknya.

Rendahnya motivasi dan hasil belajar peserta didik dapat dicariakan beberapa solusi yang mampu meningkatkan motivasi dan hasil belajar peserta didik. Solusi yang dimaksud diantaranya yaitu dengan menerapkan model pembelajaran yang mampu meningkatkan aktivitas dan kreativitas peserta didik yaitu model "Prediksi Kawan”. Model pembelajaran ini mempunyai kelebihan bila dibandingkan dengan model pembelajaran yang lain. Adapu kelebihan/keunggulan model pembelajaran "Prediksi Kawan" yaitu; 1) dapat meningkatkan kualitas pembelajaran baik motivasi maupun hasil belajarnya, 2) menumbuhkan keberanian, percaya diri selama mengikuti proses pembelajaran dikelas senyatanya, dan 3) pekerjaan/permasalahan yang diberikan oleh guru dapat diselesaikan bersama-sama dalam satu kelompok kecil dan mampu mempertanggungjawabkan kepada kelompok lain di depan kelas.

Untuk membuktikan keunggulankeunggulan model "Prediksi Kawan" perlu diadakan tindakan nyata oleh guru. Bentuk tindakan itu dilaksanakan dengan Penelitian Tindakan Kelas (PTK) dengan judul "Penggunaan Model Prediksi Kawan Pada Mata Pelajaran Matematika Peserta Didik Kelas III Semester Dua Tahun Pelajaran 2018/2019 di SD Negeri 38 Ampenan Upaya Meningkatkan Motivasi Dan Hasil Belajarnya".

\section{Rumusan Masalah}

"Bagaimana melaksanakan model Prediksi Kawan dalam pembelajaran matematika dalam upaya meningkatkan motivasi dan hasil belajar peserta didik kelas III di SD Negeri 38 Ampenan”.

\section{Tujuan Penelitian}

untuk mengetahui sejauhmana efektifitas pelaksanaan model Prediksi Kawan pada mata pelajaran matematika peserta didik kelas III semester dua tahun pelajaran 2018/2019 di SD Negeri 38 Ampenan.

\section{Manfaat Penelitian}

- Bermanfaat bagi guru selaku peneliti dalam rangka melaksanakan proses pembelajaran yang kontekstual melalu penerapan model pembelajaran "Prediksi Kawan" di kelas senyatanya serta dalam upaya perwujudan pembelajaran yang aktif, inovatif, kreatif, efektif, dan menyenangkan (PAIKEM) sehingga motivasi peserta didik dapat ditingkatkan.

- Bagi peserta didik sangat bermanfaat dalam upaya peningkatan motivasi dan hasil belajar yang berdampak meningkatnya prestasi belajar peserta didik.

\section{KAJIAN PUSTAKA \\ Kerangka teoritis \\ Motivasi Belajar}

Pengertian motivasi belajar secara umum adalah keseluruhan daya penggerak baik dari dalam diri maupun dari luar peserta didik yang menjamin kelangsungan dan memberikan arah pada kegiatan belajar, sehingga tujuan yang dikehendaki oleh subjek belajar itu dapat tercapai. Bisa dikatakan bahwa arti motivasi belajar merupakan dorongan dan semangat yang muncul dari diri peserta didik atas dasar keinginannya sendiri, yaitu suatu daya penggerak dalam diri peserta didik untuk melakukan kegiatan yang menimbulkan dan memberikan arah kegiatan belajar.

Tak dapat dipungkiri bahwa motivasi belajar merupakan salah satu aspek yang berperan signifikan dalam proses tercapainya tujuan pembelajaran dan motivasi belajar juga akan mempegaruhi dan dipengaruhi oleh aspek kognitif, afektif dan psikomotor peserta didik.

motivasi belajar mempengaruhi aspek kognitif, afektif dan psikomotor dan motivasi belajar juga dipengaruhi oleh aspek kognitif, afektif dan psikomotor jadi dapat dikatakan antara aspek-aspek tesebut memiliki korelasi. motivasi belajar berperan sebagai stimulus 
untuk merangsang minat dan gairah belajar peserta didik khususnya di Sekolah Dasar.

Motivasi sendiri terbagi dua, yaitu motivasi intrinsik dan ekstrinsik. Motivasi intrinsik adalah motivasi yang timbul dari dalam individu untuk berbuat sesuatu. Sedangkan motivasi ekstrinsik adalah motivasi yang timbulnya dari luar individu. Dalam proses belajar, motivasi mempunyai peranan yang sangat penting untuk membangkitkan semangat belajar peserta didik. Dan agar kegiatan belajar mengajar itu memberikan hasil yang efektif, maka perlu adanya usaha untuk membangkitkan motivasi belajar para peserta didik.

Dengan begitu, akan terjadinya percepatan dalam mencapai tujuan pendidikan dan pembelajaran secara khusus. Maka dari itulah, dalam hal ini seorang guru dituntut mampu menciptakan situasi belajar yang dapat merangsang dan mendorong peserta didik untuk aktif dan kreatif dalam belajar. Motivasi belajar dapat dilihat dari karakter tingkah laku peserta didik yang menyangkut minat, ketajaman perhatian, konsentrasi dan tekun mencapai tujuan. Contoh dan bentuk bentuk motivasi belajar di antaranya adalah pujian, memberi angka, hadiah, gerakan tubuh, memberi tugas, memberi ulangan, mengetahui hasil, memberi hukuman, dan lain sebagainya.

\section{Hasil belajar}

Hasil belajar merupakan bagian terpenting dalam pembelajaran. Nana Sudjana (2009: 3) mendefinisikan hasil belajar peserta didik pada hakikatnya adalah perubahan tingkah laku sebagai hasil belajar dalam pengertian yang lebih luas mencakup bidang kognitif, afektif, dan psikomotorik. Dimyati dan Mudjiono (2006: 3-4) juga menyebutkan hasil belajar merupakan hasil dari suatu interaksi tindak belajar dan tindak mengajar. Dari sisi guru, tindak mengajar diakhiri dengan proses evaluasi hasil belajar. Dari sisi peserta didik, hasil belajar merupakan berakhirnya pengajaran dari puncak proses belajar.

Benjamin S. Bloom (Dimyati dan Mudjiono, 2006: 26-27) menyebutkan enam jenis perilaku ranah kognitif, sebagai berikut:

a. Pengetahuan, mencapai kemampuan ingatan tentang hal yang telah dipelajari dan tersimpan dalam ingatan. Pengetahuan itu berkenaan dengan fakta, peristiwa, pengertian kaidah, teori, prinsip, atau metode.

b. Pemahaman, mencakup kemampuan menangkap arti dan makna tentang hal yang dipelajari.

c. Penerapan, mencakup kemampuan menerapkan metode dan kaidah untuk menghadapi masalah yang nyata dan baru. Misalnya, menggunakan prinsip.

d. Analisis, mencakup kemampuan merinci suatu kesatuan ke dalam bagian-bagian sehingga struktur keseluruhan dapat dipahami dengan baik. Misalnya mengurangi masalah menjadi bagian yang telah kecil.

e. Sintesis, mencakup kemampuan membentuk suatu pola baru. Misalnya kemampuan menyusun suatu program.

f. Evaluasi, mencakup kemampuan membentuk pendapat tentang beberapa hal berdasarkan kriteria tertentu. misalnya, kemampuan menilai hasil ulangan.

Berdasarkan pengertian hasil belajar di atas, disimpulkan bahwa hasil belajar adalah kemampuan-kemampuan yang dimiliki peserta didik setelah menerima pengalaman belajarnya. Kemampuan-kemampuan tersebut mencakup aspek kognitif, afektif, dan psikomotorik. Hasil belajar dapat dilihat melalui kegiatan evaluasi yang bertujuan untuk mendapatkan data pembuktian yang akan menunjukkan tingkat kemampuan peserta didik dalam mencapai tujuan pembelajaran. Hasil belajar yang diteliti dalam penelitian ini adalah hasil belajar kognitif IPS yang mencakup tiga tingkatan yaitu pengetahuan $(\mathrm{C} 1)$, pemahaman $(\mathrm{C} 2)$, dan penerapan (C3). Instrumen yang digunakan untuk mengukur hasil belajar peserta didik pada aspek kognitif adalah tes.

\section{Model Pembelajaran "Prediksi Kawan"}

Untuk mata pelajaran yang sering menuntut kerjasama kelompok dalam bekerja, team Building, perlu dibangun semenjak awal pelajaran. Hal tersebut dimaksudkan agar peserta didik dapat secepatnya mengenal teman-temannya sehingga pada akhirnya mereka dapat 
bekerjasama dalam kelompok. Strategi ini adalah salah satu cara yang cukup baik untuk membantu peserta didik mengenal satu sama lain.

Langkah-langkah pembelajaran:

1. Bentuk kelompok-kelompok kecil, 3-4 orang (usahakan mereka yang belum mengenal).

2. Jelaskan pada peserta didik bahwa tugas mereka adalah menebak apa jawaban yang akan di berikan oleh kawannya jika dia menyakan beberapa pertanyaan yang telah di siapkan.

3. Minta masing-masing kelompok untuk memulai dengan memilih salah seorang dari mereka untuk menjadi "subyek" tersebut. Sampaikan bahwa mereka tidak perlu takut untuk menulis prediksi yang di rasa aneh. Ketika mereka membuat dugaan jawaban, mintalah sang "subyek" untuk tidak memberi indikasi yang mengarah pada jawaban yang benar.Ketika semua selesai dengan prediksi mereka, sang "subyek" harus menjawab setiap pertanyaan.

4. Proses nomer 3 ini di lanjutkan dengan anggota yang lain sampai selesai.

\section{Hipotesis Tindakan.}

Penerapan model Prediksi Kawan dapat meningkatkan motivasi dan hasil belajar Matematika peserta didik Kelas III SD Negeri 38 Ampenan Semester dua Tahun Pelajaran 2018/2019.

\section{METODE PENELITIAN \\ Setting Penelitian}

Penelitian tindakan kelas (PTK) ini akan dilaksanakan di Kelas III SD Negeri 38 Ampenan Semester dua Tahun Pelajaran 2018/2019, dengan jumlah peserta didik sebanyak 20 orang peserta didik.

\section{Faktor yang Diteliti}

- Faktor Guru: yaitu dengan mengganti cara guru membuat Rencana Pelaksanaan Pembelajaran (RPP) dan pelaksanaannya dalam pembelajaran di kelas senyatanya dengan menerapkan model Prediksi Kawan dalam upaya meningkatkan motivasi dan hasil belajar Matematika peserta didik Kelas III SD Negeri 38 Ampenan.

- Faktor Peserta didik: yaitu peningkatan motivasi dan hasil belajar peserta didik yang terlihat pada perilaku peserta didik selama diskusi kelompok, dan pada saat mengerjakan tes tertulis.

\section{Rencana Tindakan}

kegiatan nyata di Kelas III yaitu melaksanakan proses pembelajaran dengan menerapkan model Prediksi Kawan dalam upaya meningkatan motivasi dan hasil belajar Matematika peserta didik kelas III SD Negeri 38 Ampenan Semester dua Tahun Pelajaran 2018/2019. Tindakan nyata yang dilakukan oleh guru selaku peneliti adalah dengan menggunakan siklus. Gambaran siklus dalam penelitian ini adalah sebagai berikut:

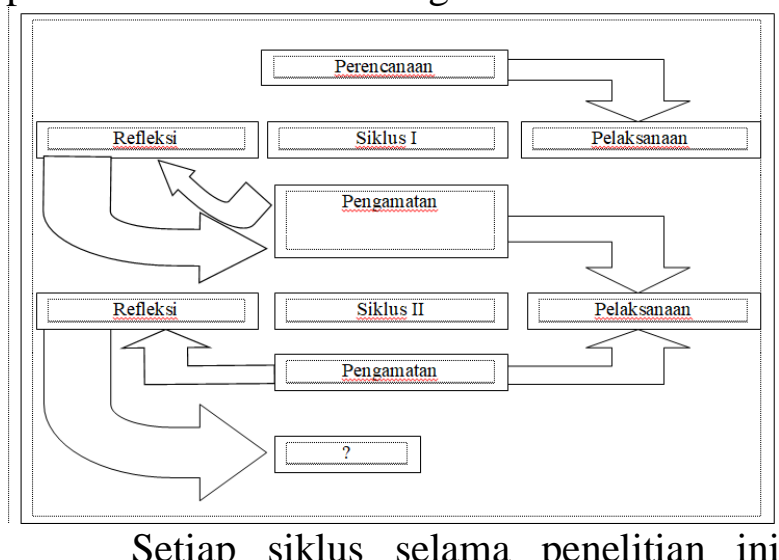

berisi 4 (empat) tahapan yaitu: 1) Perencanaan (Planning), 2) Pelaksanaan (Action), 3) Observasi (Observation), dan 4) Refleksi (Reflection).

\section{Siklus Tindakan SIKLUS I}

\section{Tahap Perencanaan (Planning)}

1. Pada tahapan ini guru selaku peneliti melakukan kegiatan-kegiatan sebagai berikut:

2. Menyusun Rencana Pelaksanaan Pembelajaran (RPP) dengan skenario sesuai dengan aturan main model pembelajaran Prediksi Kawan.

3. Menyiapkan sumber, bahan, dan semua alat yang digunakan dalam penelitian.

4. Menyusun/membuat lembar observasi guru dan lembar observasi peserta didik.

5. Menyusun alat evaluasi.

\section{Tahap Pelaksanaan (Action)}

\section{Pertemuan I}

1. Guru membagi peserta didik menjadi 5 (lima) kelompok kecil, masing-masing kelompok beranggotakan sebanyak 4 (empat) orang peserta didik. 
2. Guru menjelaskan tugas dari masingmasing kelompok. Setelah mendapatkan tugas dari guru, masing-masing kelompok mengerjakan tugas yang diberikan oleh guru.

3. Masing-masing peserta didik membuat tugas secara individual selama melaksanakan diskusi kelompok

\section{Pertemuan II}

4. Setelah selesai mengerjakan tugas dari kelompoknya, masing-masing kelompok mempresentassikan hassil kelompoknya di depan kelas

5. Tes tertulis.

\section{Tahap Observasi (Observation)}

- Observasi guru : Dilakukan oleh pengawas mata pelajaran Matematika observer sekaligus sebagai pembimbing guru dalam melaksanakan Penelitian Tindakan Kelas (PTK).

- Observasi Peserta didik : Dilaksanakan oleh guru mata pelajaran sekaligus sebagai peneliti dalam Penelitian Tindakan Kelas (PTK) pada kegiatan diskusi kelompok.

Tahap Refleksi (Reflection)

1. Renungan hasil perolehan data

2. Pengolahan dan analisa data hasil penelitian

3. Mencocokkan hasil analisa data dengan indikator keberhasilan

4. Rencana perbaikan dan tindak lanjut

\section{SIKLUS II}

Pada siklus ini semua kegiatan dan tahapan selama penelitian adalah sama, sifatnya mengulang dan memperbaiki terhadap tindakan yang masih memerlukan penyempurnaan dan pembenaran sebagaimana mestinya.

\section{Data dan Cara Pengambilannya.}

\section{Sumber Data}

Yang menjadi sumber data dalam penelitian tindakan kelas (PTK) ini adalah semua peserta didik Kelas III Semester dua Tahun Pelajaran 2018/2019 di SD Negeri 38 Ampenan dan semua tim peneliti.

\section{Jenis Data}

- Jenis data yang berasal dari guru selaku peneliti

1). Data tentang Rencana Pelaksanaan Pembelajaran (RPP)
2). Data Pelaksanaan Pembelajaran

- Jenis data yang berasal dari peserta didik :

1). Data kemajuan motivasi dari peserta didik

2). Data hasil belajar peserta didik

\section{Cara Pengambilan data}

- Data kegiatan pembelajaran diambil dari RPP yang dibuat oleh guru dan lembar observasi pelaksanaan model pembelajaran Prediksi Kawan

- Data kemajuan motivasi dan hasil belajar; diambil dari lembar observasi selama diskusi kelompok.

- Data kemajuan hasil belajar; diambil dari nilai pada saat tes tertulis yang dilaksanakan pada akhir proses pembelajaran.

Indikator Keberhasilan dan Teknik analisa data

Teknik analisa data

Untuk menganalisis data akan dilakukan melalui analisis deskriptif kuantitatif melalui pendataan, analisis dan pembahasan terhadap data yang diperoleh dengan mencocokkan tingkat keoptimalan terhadap capaian indikator keberhasilan yang ada.

\section{Indikator Keberhasilan}

- guru telah dinyatakan berhasil melaksanakan proses pembelajaran dengan model Prediksi Kawan, bila telah mencapai skor rata-rata $\geq 4,00$

- Motivasi dan hasil belajar Matematika peserta didik Kelas III dinyatakan telah meningkat jika $\geq 85 \%$ dari jumlah peserta didik telah memperoleh skor perolehan skor rata-rata $\geq 4,0$, hasil belajar dinyatakan meningkat jika $\geq 85 \%$ dari jumlah peserta didik memperoleh nilai rata-rata $\geq 75,00$ (Sesuai KKM)

\section{HASIL DAN PEMBAHASAN \\ Laporan Hasil \\ DESKRIPSI SIKLUS I}

\section{Tahap Perencanaan}

Pada tahapan ini yang telah dilakukan oleh guru selaku peneliti adalah; 1) menyusun RPP dengan skenario pembelajaran Prediksi Kaawan, 2) telah berhasil menyiapkan alat, sumber, bahan yang diperlukan dalam penelitian, 3) berhasil menyusun instrument 
observasi guru dan instrument observasi peserta didik, dan 4) menyusun alat evaluasi.

\section{Tahap Pelaksanaan \\ Pertemuan I}

1. Guru membagi peserta didik menjadi 5 (lima) kelompok kecil, masing-masing kelompok beranggotakan sebanyak 4 (empat) orang peserta didik.

2. Guru menjelaskan tugas dari masingmasing kelompok. Setelah mendapatkan tugas dari guru, masing-masing kelompok mengerjakan tugas yang diberikan oleh guru.

3. Masing-masing peserta didik membuat tugas secara individual selama melaksanakan diskusi kelompok

\section{Pertemuan II}

4. Setelah selesai mengerjakan tugas dari kelompoknya, masing-masing kelompok mempresentassikan hassil kelompoknya di depan kelas

5. Tes tertulis

\section{Tahap Observasi}

Observasi guru memperoleh skor ratarata sebesar $(3,36)$ pertemuan II $(3,71)$, observasi peserta didik memperoleh skor ratarata pertemuan I $(3,27)$ pertemuan II $(3,51)$. Dampak dari hasil peningkatan motivasi dan hasil belajar dalam bentuk nilai hasil tugas dan tes tertulis yaitu $(70,75)$ dan $(58,35)$.

\section{Tahap Refleksi}

1. Renungan data hasil perolehan data pada siklus I

2. Pengolahan data hasil observasi guru, peserta didik dan tes tertulis.

3. Mencocokkan hasil yang ada dengan Indikator keberhasilan.

4. Merencanakan perbaikan terhadap jenis tindakan yang menyebabkan belum tuntas Indikator keberhasilan. Oleh karena Indikator keberhasilan belum terbukti maka penelitian dilanjutkan ke siklus II.

\section{DESKRIPSI SIKLUS II}

\section{Tahap Perencanaan}

Pada tahapan ini jenis kegiatan yang dilakukan masih mengacu pada kegiatan siklus I, bedanya hanya terjadi perbaikan seperlunya yaitu: 1) penyusunan RPP dengan mengacu pada model Prediksi Kaawan dan penyempurnaan pada bagian skenario pembelajaran, 2) menyiapkan alat, sumber, bahan yang diperlukan dalam proses tindakan dikelas senyatanyan, 3) menyiapkan lembar observasi guru dan lembar observasi peserta didik sebagaimana pada siklus I, 4) menyiapkan alat evaluasi sebagaimana yang telah dibuat pada siklus I.

\section{Tahap Pelaksanaan}

Secara umum tahapan pelaksanaan proses pembelajaran pada siklus II ini masih mengacu pada pelaksanaan proses pembelajaran sebelumnya. Pemecahan yang dilakukan pada proses pembelajaran ini adalah: 1) pelaksanaan proses diskusi kelompok kecil lebih dioptimalkan, 2) pelaksanaan pembimbingan kelompok sekaligus observasi peserta didik lebih di efektifkan. Utamanya pengamatan peserta didik yang termotivasi, yang kurang motivasi, peserta didik yang tidak termotivasi, dengan harapan proses analisa data lebih signifikan, 3)laporan hasil kerja kelompok yang dibuat secara individu lebih difokuskan, dan 4) pelaksanaan tes tertulis yang merupakan dari peningkatan motivasi dan hasil belajar peserta didik lebih diperketat.

\section{Tahap Observasi}

Observasi guru memperoleh skor ratarata sebesar $(4,36)$ pertemuan II $(4,71)$, observasi peserta didik memperoleh skor ratarata pertemuan I $(4,22)$ pertemuan II $(4,51)$. Dampak dari hasil peningkatan motivasi dan hasil belajar dalam bentuk nilai hasil tugas dan tes tertulis yaitu $(76,70)$ dan $(81,80)$.

\section{Tahap Refleksi}

1. Renungan atas perolehan data hasil observasi guru, observasi peserta didik, dan hasil tes tertulis sebagai dampak dari peningkatan motivasi dan hasil belajar peserta didik di kelas senyatanya.

2. Pengolahan data hasil observasi guru, observasi peserta didik dan tes tertulis

3. Mencocokkan perolehan data hasil tindakan dengan Indikator keberhasilan yang telah ditetapkan.

4. Guru memberikan hadiah/reward kepada semua peserta didik Kelas III atas keberhasilannya dalam upaya meningkatkan motivasi dan hasil belajar yang berdampak terhadap perolehan hasil 
belajar sesuai dengan KKM yang telah ditetapkan.

\section{Pembahasan}

\section{SIKLUS I}

\section{Tahap Perencanaan}

Peneliti menyusun RPP dengan skenario penerapan model Prediksi Kawan, menyiapkan alat, sumber, bahan yang diperlukan dalam proses pembelajaran, menyiapkan instrument observasi guru maupun instrument observasi peserta didik. Ada kendala yang dihadapi selama persiapan alat dan bahan pembelajaran, tetapi setelah meminta petunjuk kepada pembimbing kendala yang dihadapi pun dapat diatasi dengan baik.

\section{Tahap Pelaksanaan}

a. Bentuk kelompok-kelompok kecil, 3-4 orang (usahakan mereka yang belum mengenal).

b. Jelaskan pada peserta didik bahwa tugas mereka adalah menebak apa jawaban yang akan di berikan oleh kawannya jika dia menyakan beberapa pertanyaan yang telah di siapkan.

c. Minta masing-masing kelompok untuk memulai dengan memilih salah seorang dari mereka untuk menjadi "subyek" tersebut. Sampaikan bahwa mereka tidak perlu takut untuk menulis prediksi yang di rasa aneh. Ketika mereka membuat dugaan jawaban, mintalah sang "subyek" untuk tidak memberi indikasi yang mengarah pada jawaban yang benar.Ketika semua selesai dengan prediksi mereka, sang "subyek" harus menjawab setiap pertanyaan.

d. Proses nomer 3 ini di lanjutkan dengan anggota yang lain sampai selesai.

Kegiatan pembelajaran diakhiri dengan tes tertulis, hal ini dimaksudkan untuk mengetahui dampak positif dari peningkatan motivasi dan hasil belajar Matematika peserta didik Kelas III SD Negeri 38 Ampenan Semester dua Tahun Pelajaran 2018/2019 dengan penerapan model Prediksi Kawan. Asumsi bila motivasi dan hasil belajar meningkat maka akan berdampak meningkatnya hasil belajar peserta didik.

\section{Tahap Observasi}

Observasi guru memperoleh skor ratarata pertemuan I $(3,36)$ pertemuan II $(3,71)$, hasil observasi peserta didik dalam upaya peningkatan motivasi dan hasil belajar Matematika peserta didik Kelas III Semester dua Tahun Pelajaran 2018/2019 di SD Negeri 38 Ampenan diperoleh skor rata-rata pertemuan I $(3,27)$ dan pertemuan II $(3,51)$. Dampak dari peningkatan motivasi/belum meningkatnya motivasi dan hasil belajar peserta didik salah satunya dengan nilai tugas dan hasil tes tertulis yang materinya hanya sekitar yang diajarkan pada saat itu juga, diperoleh nilai rata-rata $(70,75)$ dan $(58,35)$ kategori cukup.

\section{Tahap Refleksi}

Hasil analisa data peningkatan motivasi dan hasil belajar pada siklus I pertemuan II ini $(3,51)$ sedangkan yang diminta dalam Indikator keberhasilan $(\geq 4,0)$, ini artinya belum berhasil. Karena Indikator keberhasilan belum tercapai, penelitian tindakan kelas (PTK) dilanjutkan ke siklus II dengan harapan optimalisasi penerapan strategi pembelajaran dengan model Prediksi Kaawan dapat meningkatkan motivasi dan hasil belajar Matematika peserta didik Kelas III Semester dua Tahun Pelajaran 2018/2019 di SD Negeri 38 Ampenan.

\section{SIKLUS II}

\section{Tahap Perencanaan}

Peneliti menyusun Rencana Pelaksanaan Pembelajaran (RPP) dengan memperhatikan kesalahan-kesalahan pada siklus I. peneliti lebih memfokuskan tentang Rencana strategi jitu sehingga proses pembelajaran dengan model Prediksi Kawan dapat terelaisasi dengan baik, karenanya dalam penyusunan skenario benar-benar dirinci dari tiap aspek pada proses pembelajaran dengan Prediksi Kawan. Sebelum proses pembelajaran dilaksanakan, peneliti menyiapkan semua alat, bahan, dan segala sesuatunya sehingga dalam pelaksanaan proses pembelajaran berjalan sesuai dengan skenario yang telah direncanakan. Agar proses pembelajaran dapat teratasi maka peneliti juga menyiapkan lembar observasi guru dan lembar observasi peserta didik sebagai tolak ukur ketercapaian peningkatan motivasi dan hasil belajar 
Matematika peserta didik Kelas III SD Negeri

38 Ampenan.

\section{Tahap Pelaksanaan}

Pada tahap pelaksanaan di siklus II ini pada dasarnya masih mengacu pada pelaksanaan siklus I, yaitu penerapan model Prediksi Kawan. Bedanya pada siklus ini lebih dioptimalkan.

\section{Tahap Observasi}

Pada siklus II ini hasil observasi memperoleh skor rata-rata pertemuan I $(4,36)$ dan pertemuan II $(4,71)$, Upaya meningkatkan motivasi dan hasil belajar Matematika peserta didik Kelas III Semester dua Tahun Pelajaran 2018/2019 di SD Negeri 38 Ampenan diperoleh skor rata-rata pertemuan I $(4,22)$ dan pertemuan II $(4,51)$, sebagai tolak ukur keberhasilan proses pembelajaran adalah hasil belajar peserta didik meningkat, dari data nilai tugas dan hasil perolehan nilai rata-rata tes tertulis adalah $(76,70)$ dan $(81,80)$ ini berarti mengalami peningkatan yang signifikan.

\section{Tahap Refleksi}

Hasil analisa data peningkatan motivasi dan hasil belajar peserta didik pada siklus II pertemuan II adalah (4,51) sedangkan Indikator keberhasilan $(\geq 4,0)$. Ini artinya pada siklus II hasilnya telah melampaui Indikator keberhasilan, sedangkan hasil belajar rata-rata 79,55 dari indikator keberhasilan $\geq 75,00$, artinya telah melampaui indikator keberhasilan yang ditentukan. Karena Indikator keberhasilan telah terbukti, maka tidak perlu ada upaya perbaikan dan penyempurnaan. Model Prediksi Kawan telah mampu meningkatkan motivasi dan hasil belajar peserta didik yang ditandai dengan tercapainya Indikator keberhasilan dan terjadinya peningkatan hasil belajar peserta didik. "Penelitian Tindakan Kelas (PTK) dihentikan pada siklus II dengan hasil memuaskan."

\section{Simpulan}

Data komulatif dari hasil penelitian tindakan kelas (PTK) dari siklus I ke Siklus II

adalah Sebagai
\begin{tabular}{|c|l|c|c|c|c|c|}
\hline No & Jenis Kegiatan & $\begin{array}{c}\text { Indikator } \\
\text { keberhasilan }\end{array}$ & Pertemuan & Siklus I & Siklus II & Keterangan \\
\hline \multirow{2}{*}{1.} & \multirow{2}{*}{ Observasi Guru } & $\geq 4,00$ & I & 3,36 & 4,36 & Tuntas \\
\cline { 2 - 7 } & & $\geq 4,00$ & II & 3,71 & 4,71 & Tuntas \\
\hline \multirow{2}{*}{2.} & Observasi & $\geq 4,00$ & I & 3,27 & 4,22 & Tuntas \\
\cline { 2 - 7 } & Peserta didik & $\geq 4,00$ & II & 3,51 & 4,51 & Tuntas \\
\hline \multirow{2}{*}{3.} & Nilai Tugas & $\geq 75,00$ & & 70,75 & 76,70 & Tuntas \\
\hline \multirow{2}{*}{4.} & Nilai Tes & $\geq 75,00$ & & 58,35 & 81,80 & Tuntas \\
\hline
\end{tabular}

Penerapan model Prediksi Kawan sangat efektif upaya untuk meningkatkan motivasi dan hasil belajar Matematika peserta didik Kelas III Semester dua Tahun Pelajaran 2018/2019 di SD Negeri 38 Ampenan. Fakta telah menunjukkan perolehan rata-rata skor motivasi dan hasil belajar peserta didik pada siklus I (3,39), sedangkan pada siklus II $(4,37)$, hasil belajar siklus I $(64,70)$ dan Siklus II (79,55) sudah melampaui Indikator keberhasilan yang ditetapkan. Penelitian dinyatakan "berhasil" dan dihentikan pada siklus II.

\section{Saran}

Disarankan kepada guru sejawat untuk melaksanakan Penelitian Tindakan Kelas (PTK) dalam upaya untuk meningkatkan motivasi dan atau hasil belajar peserta didik sesuai dengan mata pelajaran masing-masing.

Disarankan kepada para semua peserta didik Kelas III SD Negeri 38 Ampenan untuk membiasakan belajar dengan model yang kontekstual utamanya strategi yang mampu membangkitkan motivasi dan hasil belajar peserta didik yang dampaknya hasil belajar dapat ditingkatkan seperti yang diharapkan.

\section{DAFTAR PUSTAKA}

Anonim, 2019, macam-macam pembelajaran aktif, dalam http://blog.unnes.ac.id/akaat/2016/04 /29/macam-macam-pembelajaranaktif/, yang diambil pada tanggal 15 Januari 2019 pada pukul 17.26 wita.

Anonim, 2019, motivasi belajar, dalam https://www.rijal09.com/2016/03/mo tivasi-belajar.html, yang diambil pada tanggal 15 Januari 2019 pada pukul 17.50 wita.

Anonim, 2019, Pengertian Hasil Belajar, dalam

https://www.zonareferensi.com/peng ertian-hasil-belajar/, yang diambil pada tanggal 18 Januari 2019, pada pukul 10.20 wita. 
Anonim, 2019, Pengertian Hasil Belajar, dalan https://eprints.uny.ac.id/9829/2/bab2. pdf, yang diambil pada tanggal 18 Januari 2019 pada pukul 10.14 wita

Anonim, 2019, Pengertian Motivasi Belajar, dalam

https://www.zonareferensi.com/peng ertian-motivasi-belajar/, yang diambil pada tanggal 15 Januari 2019 pada Pukul 17.45 Wita.

Arikunto, s. 2009, Penelitian Tindakan Kelas, Jakarta : Bumi Aksara.

Harun Rasyid dan Mansur, 2008, Penilaian Hasil Belajar, Bandung : CV Wacana Prima.

Lukmanul A, 2008, Perencanaan Pembelajaran, Bandung : CV Wacana Prima.

Mukhtar, 2003, Prosedur Penilaian, Jakarta : Rineka Cipta.

Nurhadi, 2003, Yasin ,B dan Sendule.A, 2003, Kontekstual dan Penerapannya dalam KBK, Malang : Unitipetas Negeri Malang.

Sardiman, 2007, Indikator Dan Motivasi dan hasil belajar Mengajar, Jakarta : Raja Grafindo Perkasa.

Supriono, 2009, Cooperative Learning Teori dan Aplikasi PAIKEM, Yogyakarta : Pustaka Pelajar.

Susilawati, E., Sarnita, F., Gumilar, S., Erwinsyah, A., Utami, L., \& Amiruddin, A. (2019, November). Using inductive approach (IA) to enhance students' critical thinking (CT) skills. In Journal of Physics: Conference Series (Vol. 1280, No. 5, p. 052035). IOP Publishing. 